\title{
Leaving Islam for Christianity: Asylum Seeker Converts
}

\author{
Nora Stene
}

This chapter presents a case study from Norway, and explores why and how some asylum seekers leave one religion for another: more specifically Islam for Christianity. The context of their conversion is migration and the difficult situation of asylum seekers. The chapter also highlights perspectives and methodologies especially relevant to this field of study.

There are no available official statistics on the number of asylum seeker converts in Norway. However, the Norwegian Immigration Appeals Board (UNE) estimates that between 2001 and 2015 approximately $95^{\circ}$ individuals converted from Islam to Christianity - listing fear of religious persecution as support for their asylum appeals. The great majority of them were from Iran or Afghanistan, but UNE data has registered smaller numbers of converts from a total of 23 different countries (details in Stene 2016, personal communication UNE 2017). It should be noted that in order to be considered a convert by the UNE there must be an announcement of faith, baptism, and attachment to a local Christian congregation (UNE 2016). The actual number of converts may also be higher than the figure given above, as asylum seekers may not mention conversion in their applications -or appeals.

The UNE has observed that conversions/baptisms usually take place during the appeal-process, after an initial asylum application has been rejected. In this period a number of asylum seekers have contact with Christian congregations (UNE 2016). Clearly critical to certain kinds of active proselytisation among asylum seekers, the UNE, human rights- and church umbrella-organisations have issued guidelines to protect asylum seekers from what has been termed "unwanted attention" from missionaries (details in Stene 2016:207). The Church of Norway's charter emphasises that converts may face negative reactions: "If a Muslim is to be baptised, it will also be necessary to discuss [with the baptismal candidate] the consequences baptism may have in the baptismal candidates' networks both in Norway and in country of origin" (Bishops' Council 2016:8, my translation). The fact that guidelines of this kind exists, underscores 
the existence of missionary work amongst asylum seekers. The number of converts also points to dynamics that are worth further investigation.

\section{$2 \quad$ Previous Research and Empirical Material}

There is little existing research on religious conversion amongst asylum seekers. However, some empirical material is found in research on migrants. Perspectives, models and findings from a selection of these studies are presented here, and further developed in the analysis of new material below.

From the field of migration studies, Marzouki and Roy (2013) underline the importance of understanding both the individual and relational character of conversion. Their book includes Le Pape's model of 'grammar for conversion.' Based on interviews conducted in France, Le Pape shows how certain rules must be respected for a religious conversion to be understood and accepted in society. According to his understanding, conversion must be validated not only by the faith-community, but also by a broader social group. In the broader group, parental reactions were found to be important, and often the most difficult to handle (Le Pape 2013).

Another in-depth migration study is made by Akcapar (2006). Based on fieldwork with Iranian converts in Turkey, Akcapar emphasises that conversion often runs parallel to migration. He highlights the discontinuity in the lives of migrants, alongside the continuity in efforts to retain family values and mother tongue. Conversion is discussed as a migration strategy in a transit country, possibly used to manipulate migration authorities. Akcapar portrays internal strife among Iranians related to conversions, as well as the deep identification many seem to have developed with Christianity and their new-found faithcommunities. Similar findings are highlighted in Spellman's study of Iranian networks in Britain (Spellman 2004).

Theological studies have had a focus on growth in the number of converts from Islam to Christianity worldwide. Miller and Johnstone (2015) discuss the possible over- and underestimation of available figures, as well as new selfidentifications like "Muslim-background Believer" and "Muslim Follower of Christ," and the fact that many converts avoid the term "Christian." Miller and Johnstone highlight an early conversion-wave in Indonesia in the 196os and similar developments amongst Iranians some decades later. Intensified missionary work, contact with indigenous Christians, globalisation, new media, emigration and turmoil in the Muslim World are listed as explanations for why Muslims convert. Concerning Iranians, Miller argues that leaving Islam may be a way of remaining "Persian" in the context of migration, as Islam is associated 
with the Arab world. Christianity is seen as a religion where "Persian-ness" is given ample room (2012; 2015). Like Marzouki and Roy (2013), Miller underscores that a high number of ex-Muslims become Pentecostals, though Miller also stresses that conversion to different denominations is known (2014; 2015).

Human rights studies inspired my own exploration of Christian missionaries working amongst asylum seekers (Stene 2016). Based on fieldwork in Norway, my study shows how a broad variety of denominations are involved. Some missionaries offer diaconal services; others run intense proselytisation programs and many combine evangelisation and practical help. Missionaries with a migrant background were found to work mainly among those with similar backgrounds (see also Synnes 2012). Some missionaries were found to actively use the language of human rights to defend their activities, though not all. The article argues that this kind of missionary work must be understood within the context of Christian activism, in which asylum seekers are viewed as people in desperate need, but also as a new, local "mission field."

Website studies of apostasy/conversion narratives are important in mapping out religious change. Enstedt and Larsson (2013) discuss apostates' perceptions of Islam. Through text analysis, they underscore how the religion left behind (Islam) is presented as evil, irrational and anti-modern, and how this corresponds to broader anti-Muslim discourses and ideas of the New Atheist Movement (see also Larsson 2015, 2016).

Islamophobia is also explored by Marti (2016). Based on fieldwork in North Carolina, Marti's study presents an immigrant Christian convert who is still associated with Islam by his congregation, through ideas of interwoven ethnoreligious identities. Marty shows how the convert remains the "other" and uses this to his own advantage; the notion of persecution under Islam gives him the symbolic power of being close to martyrdom. The convert also remains the raw and exotic ex-Muslim who gives legitimacy to his congregation as he embodies a long-awaited religious revival.

In contrast to the image of Islam mentioned above, Speelman's interviewbased study of converts from Islam to Christianity in the Netherlands (2006), stresses how two "Islams" are often present in the same narrative; one of strict rules and one of a loving parent. These stories typically include the following steps: crisis, contact with believers and a Bible, and finally conversion- when a distant or absent God becomes a God of utmost importance. Echoing Le Pape's model, parents are usually part of the narrative's turning point; conversion happens after their death, a family break-up or a reconciliation-process.

Migrants continue to relate to their country of origin. Studies from "sendercountries" capture important aspects, for example that leaving Islam does not necessarily mean leaving a Muslim identity. With empirical material from the 
Middle East, both Kraft (2013) and Barnett (2008) show some of the complex ways conversions are negotiated (and often hidden) in family-oriented societies. In the following, we do not meet such "closeted apostates" (see Cottee 2015), but rather converts who have taken a step out into the open.

\section{New Findings on Asylum Seekers leaving Islam for Christianity}

This section analyzes fieldwork material from 2014 (details in Stene 2016), and 11 follow-up interviews from 2017 (seven men; four women). The stories of four interviewees have been chosen to give empirical insight and to offer a nuanced image of asylum seekers' conversion narratives. Analysis point back to findings from previous research (see above) and is further developed in the conclusion. To protect anonymity pseudonyms are used and some non-relevant details have been altered.

'Bahram' is from Iran. Among those interviewed, he is the only one who obtained residence prior to his conversion. His religious change was depicted both as sudden and as an on-going process. He arrived in Norway with his asylumseeking parents. He describes them as "liberal Muslims," but adds that he never practiced "any of that stuff" after they died. Everyday life had not been easy for Bahram. At one point, he started drinking heavily. Just when he thought he could fall no further a fellow drinking friend turned up and proclaimed his newfound faith in Jesus. Confused, Bahram started to read the Bible his friend left behind: "I read for three days and could not stop crying." Soon after, he approached a Pentecostal congregation and asked to be baptised, but was told that he had to be taught more about Jesus first: "From the moment I read the Bible I knew I believed, but I had to get to know Jesus -properly." In the congregation a small fellowship communicated in Farsi, which is important to Bahram: "As Persians, we don't like Arabs. Islam is an Arabic religion. When I found Jesus, I did not need anything Arabic anymore." As noted by Miller (2015b), this conversion seems to strengthen Bahram's ethnic, Persian identification.

The religion Bahram left behind was in many ways described as foreign. His conversion gave him a new identity, along with a calling to missionary work. Speaking Farsi, he joined a prayer group that attracts asylum-seeking Iranians: "Many have a real thirst for God, even if some first come to us because they are curious or just bored at the reception center, or think they can get residence by becoming Christian..." In this quote, Bahram touches upon what Ackapar (2006) calls "conversion as migration strategy." This pinpoints the imposterproblem: are those who convert true believers, or just pretending? Society at large is especially concerned with this question when it comes to asylum 
seekers. To use Le Pape's model (2013); asylum seeker converts need not only to be accepted by a new faith-community, their conversion must also be public and validated by a broader social group, in this case including immigration authorities. Bahram ends his story with reference to the problem of being seen as an imposter: "I have been a Christian for many years. I did not need to change religion; I already had a residence permit. Still people don't believe me. I try to convince them..." This striving to have a conversion accepted by society may be seen as part of the on-going public conversion of many asylum seeker converts.

'Sherif' is from Iraq. His first application for asylum was rejected. It was accepted only after several appeals during a difficult 12-year period: "I could never have managed without Jesus," he says. Like what happens to many asylum seekers, the long appeal-period increased his contact with Christianity, as well as his conversion opportunities. He first met Christian activists at asylum reception centers. Sherif describes how people from the local Church of Norway collected asylum seekers, transported them to church services and even invited them into their homes: "They were so kind, but I didn't understand much of what they said. I didn't speak Norwegian at that time." For Sherif, the turning point came when he met Arabic-speaking Pentecostals: "They gave me a Bible in Arabic and took me to their congregation. I read the whole Bible and I believed. I told them 'Jesus is my Lord' and they baptised me." However, remembering his first contact with Lutherans, Sherif later found a Lutheran congregation, where he now feels at home.

As opposed to Bahram, Sherif underlines that his conversion was not sudden: "It was something from my childhood. I knew churches from Iraq. I liked them; songs came out their doors. Sometimes when I went to Baghdad where nobody knew me, I visited churches and lit candles." Sherif explains his conversion through reference to his childhood experiences: "I always liked the Christians. I had Christian teachers in school and was drawn to their faith, even if I didn't know it." Like other converts I talked to, he describes long-lasting ties to Christianity; they stem from his childhood and even further back into history. It is important to him that "his" Iraq once was a Christian area. These stories of pre-migration connections to Christianity can be analysed as rhetorical devices used to show the sincerity of his conversion, because like Bahram, Sherif still has to face societies' scrutiny of "new" converts.

In Sherif's memory, religion (Islam) was practiced in a good way in his village. He has little negative to say about the religion left behind. It only lacked Jesus, and he believes relatives would become Christians: "If only they really knew Jesus..." The image given is one of righteous people who have not heard the gospel - yet. Like in Speelman's study (2006), two "Islams" are present; positive images connected to village life and older relatives alongside negative 
images: "Muslims know about my faith. At times this can be dangerous, because leaving Islam can make them see you as a traitor, not only towards Islam, but also towards your country, your family... So if my car is bumped, first I always think: 'Muslims did this to me." This double-image of Islam ran through many of the stories I heard; the Islam of up-right Muslim relatives, and the Islam that causes fear.

'Sandy' is from the Balkans. She arrived in Norway with a small child, having left an older one behind. Her application for asylum was turned down. Years of appeals followed. During these years she got to know her Christian neighbors. They invited her along to Norwegian-classes for asylum seekers and lowchurch meetings. Sandy describes her earlier life like this: "Those days I cried and cried all day, I did not sleep at all. In the end, I did not want to live. I worried sick for the child I had to leave. I only relaxed inside the church; only there my problems were left behind. There my Christian friends helped me." Sandy's case illustrates the importance of group dynamics when it comes to religious change. As referred to above (Stene 2016), Christian evangelism and diaconal service often blend. Groups embrace potential converts, and some convert. In the conversion narratives of all of my interviewees, practical help from a local community was stressed as essential. In Sandy's case, her new network helped with every aspect of life, social, financial and legal. To understand the on-going group dynamics, I will expand on Akcapar's term "conversion as migration strategy," and highlight "conversion as integration strategy." To some asylum seekers a new religious identity may become a way into (a section of) broader society. Should residence permits be granted, their "reception-congregations" provide a community where they already belong.

Sandy calls the pastor-couple of her congregation "my new parents." She has not told her biological parents about her conversion and does not intend to: "We have very little contact. They will not understand." The phrase "my new parents" may be connected to a theme touched upon by previous researchers. As argued by Marzouki and Roy (2013) and Le Pape (2013), conversion may be individual, but it also has a relational aspect. Relation to parents seems to be especially important. In the stories of those I interviewed, a family rupture often preceded the conversion. Some converted after the death of parents (like Bahram), or after the loss of regular contact (like Sherif and Sandy). Some struggled to keep ties alive- or concentrated on other relatives than parents. Like the Middle Eastern converts discussed by Kraft (2013) and Barnett (2008), relations with family members were generally portrayed as important, despite the difficulties some converts experienced.

In Sandy's case, her congregation kept praying that the problem of her broken family might be solved. Then one day: “... like a miracle my sister arrived 
in Norway, with my child!" Overjoyed, Sandy turned to the congregation she believed had spurred the miracle. Previously she had not fully identified as Christian, now she did. She joined the local church with her children and they were baptised together: "...because we were finally together." The turning point in this story was not the growth of personal faith, but the resolution of a crisis attributed to a miracle. To Sandy, the natural consequence was conversion.

'Mansur' is from Afghanistan. In his story an outer and inner journey run parallel. He cries as he recounts how he barely survived en route to Europe. He did not want to beg, but was forced to contact handout places. Some food packages included biblical quotes. He was curious about the Bible and the Christians: "They sang even if they did not know how to sing! And why give things for free to those you do not know?" When he arrived in Norway, he had lots of spare time and studied the Bible. He also continued to read works of Muslim scolars, like he had done before, but what they wrote disappointed him. Compared to the converts presented above, Mansur gave harsh statements about Islam. Like apostates in Enstedt/Larsson (2013) and Larsson (2016), he portrayed Islam as a straitjacket and message of punishment. These negative images were contrasted to Christianity, explained as a religion of generosity and forgiveness: "It answered all my questions about life. I found a church and finally felt safe. I spent days and even nights sitting there. One night I dreamt of being guided through a house, and recognised it as my church. The dream strengthened my faith."

Mansur's narrative is focused on inner change. He portrays himself as a seeker looking for religious answers. He was in danger, but was saved; in need, and met helping hands. Like many asylum seekers, he identifies the Bible as essential to his conversion. This may be explained by the centrality of the Bible in Protestant Christianity, which is the type of Christianity most asylum seekers in Norway meet. To Mansur, the content of the Bible was important. To others, possessing the book seemed just as important. Several recounted how they, in a miraculous way, read it all in a few days. Besides reading the Scripture, many conversion narratives also focused on church-buildings. Like Sandy, Mansur depicts the church as his place of refuge. Explanations for this are not easily found by reference to Protestant Christianity, which concentrates more on faith than buildings. However, the political context is relevant; asylum seekers often live in fear of an expulsion order, but they also know that Norwegian police do not enter churches to carry out such orders. Stories of peace inside church-rooms may therefore be related to the storyteller's legal status. Furthermore, the narratives underline how conversion "takes place" inside rooms and buildings. Not only congregations, but also buildings embrace converts, thereby stressing a conversion's tangible aspect. To Mansur, the local church 
is important: "It is my new home." So far little explored, this perspective from material culture studies shed light on the importance of physical structures in conversion narratives. It is a perspective that may prove useful for further studies in this field.

The four stories above are personal and unique. However, they all have detectable patterns relevant to the topic of this book.

To some asylum seekers, what follows leaving (a particular) religion is religious conversion. The conversion may be part of a migration and/or integration strategy. As migrants, individuals are in a vulnerable situation and new socio-religious networks develop into important safety nets. Life prior to conversion is often portrayed as a perpetual crisis and conversion as a solution. To some converts, blending into new, local networks becomes paramount. Some also nurture ethno-religious identifications, like being Christian-Persian. To all, the relational character of conversion remains essential, especially relating to close relatives. However, changing religious affiliation may lead to a break of contact with family and kin. For some asylum seekers this break of contact has provided space for new relationships.

In this study, a double-image is given of the religion left behind. As exMuslims, interviewees expressed both critical and moderate views on Islam, often alongside appreciations of Muslim relatives. Many converts did not dwell on leaving, but rather on joining. In other words, they did not stress apostasy as much as newfound faith. These findings stand in interesting contrast to the one-sided negative representations of Islam found on apostate webpages, as discussed by Enstedt and Larsson (2013). Difference in method and material may have shaped these findings; web-based text analysis and fieldwork give different empirical bases. These findings underline that people express themselves differently on webpages and in face-to face situations. In future research, both methodologies are clearly useful.

As mentioned above, some converts in the Middle East use terms like "Muslim-background Believer" or "Muslim Follower of Christ." In this study of asylum seekers, all the converts called themselves Christians. I argue that this is connected to the fact that they want their religious change to be public and recognised by the authorities. As asylum seekers, they cannot use the sometimes fuzzy-boundary conversions of the Middle East. They must show a clear break if they are to be given asylum due to fear of religious persecution. This may explain their often unambiguous presentation of a new religious identity. 
Although we do not know how many asylum seekers that converts from Islam to Christianity, such cases are well known to immigration authorities and church congregations. As this case study shows, for some religious change does not mean rejecting religion altogether; but leaving one religion to embrace another. Our studies of "leaving religion" need to include these groups, in order to further investigate how religious affiliations can and does change.

\section{References}

Akcapar, S. 2006. "Conversion as a Migration Strategy in a Transit Country: Iranian Shiites Becoming Christians in Turkey." International Migration Review. 40:4, 817-853.

Barnett, J. 2008. "Conversion's Consequences: Identity, Belonging and Hybridity amongst Muslim Followers of Christ." MA thesis. Redcliffe College, England.

Bishops' Council/Bispemøtet. 2016. Dåp av asylsøkere (Baptism of asylum seekers). Oslo: Booklet from Church of Norway.

Cottee, S. 2015. The Apostates: When Muslims Leave Islam. London: Hurst and Co.

Enstedt, D., and Larsson, G. 2013. "Telling the Truth about Islam? Apostasy Narratives and Representations of Islam on WikiIslam.net." CyberOrient. 7:1.

Larsson, G. 2016. "Most Muslims are Like You and I, But 'Real' Muslims..." Journal of Muslims in Europe. 5, 205-223.

Larsson, G. 2015. "Apostasy in the West: A Swedish Case Study." In Camilla Adgang et al. eds, Accusations of Unbelief in Islam: A Diachronic Perspective on Takfir. Leiden: Brill, 381-392.

Kraft, K. 2013. "Coming Out' as a Faith Changer: Experiences of Faith Declaration for Arabs of a Muslim Background who Choose to Follow a Christian Faith." Transformation. 30:2, 96-106.

Le Pape, L. 2013. "Converts at Work: Confessing a Conversion." In N. Marzouki and O. Roy eds, Religious Conversions in the Mediterranean World. Houndmills: Palgrave MacMillan, 98-114.

Marti, G. 2016. “'I Was a Muslim, But Now I Am a Christian": Preaching, Legitimation, and Identity Management in a Southern Evangelical Church." Journal for the Scientific Study of Religion. 55:2, 250-270.

Marzouki, N., and Roy, O., eds. 2013. Religious Conversions in the Mediterranean World. Houndmills: Palgrave MacMillan.

Miller, D., and Johnstone, P. 2015. "Believers in Christ from a Muslim Background: A Global Census." Interdisciplinary Journal of Research on Religion. 11, 1-20.

Miller, D. 2015. "Power, Personalities and Politics. The Growth of Iranian Christianity since 1979." Mission Studies. 32, 66-86. 
Miller, D. 2014. "An interview with Moh-Christoph Bilek: Algerian, Berber, Ex-Muslim and Catholic." At www.GlobalMissiology.org. Accessed 10/3/2017.

Miller, D. 2012. "Iranian Diaspora Christians in the American Midwest and Scotland." At www.GlobalMissiology.org. Accessed 10/3/2017.

Speelman, G. 2006. "Continuity and Discontinuity in Conversion Stories." Exchange. $35: 3,304-335$.

Spellman, K. 2004. Religion and Nation. Iranian Local and Transnational Networks in Britain. New York: Berghahn Books.

Stene, N. 2016. "Christian Missionaries and Asylum Seekers: A Case Study from Norway." Nordic Journal of Human Rights. 34:3, 203-221.

Synnes, R. 2012. Kristne migrantmenigheter i Oslo (Christian migrant-congregations in Oslo). Oslo: KIFO.

UNE (Immigration Appeals Board). 2016. «Forfølgelse på grunnlag av religion. Praksisnotat» (Persecution based on religion. Note on praxis). At www.une.no/Praksis2/ Notater/. Accessed 10/3/2017. 